\title{
Guinea Worm, Leg Ulcer, and Malignant Change in Nigeria: Another Case Report
}

\author{
Wilson IB Onuigbo ${ }^{1 *}$ and Joseph 0 0jukwu ${ }^{2}$ \\ Departments of Pathology and Surgery, Nigeria \\ Enugu Specialist Hospital, Enugu, Nigeria
}

Submission: July 16, 2018; Published: August 09, 2018

*Corresponding author: Wilson IB Onuigbo, Departments of Pathology and Surgery, Nigeria, Email: wilson.onuigbo@gmail.com

\section{Abstract}

In Orthopedics and Rheumatology Open Access Journal (OROAJ), Previously a case was reported of malignant change in the leg ulcer of a Nigerian. Here, another case is being presented in like manner. In conclusion, the good news is that the eradication of the disease has been achieved worldwide.

Keywords: Skin; Guinea worm; Ulcer; Malignant change; Developing community

\section{Introduction}

This Journal carried our odd report of a 50-year-old woman whose leg ulcer due to old infection of guinea worm became malignant [1]. This deferred from the standard picture painted in a standard tropical text book as "An inflammatory arthritis due to the discharge of larvae into the joint, an arthritis due to secondary bacterial infection" [2]. Here, as malignancy supervened again, the case is deemed to be worthy of documentation.

\section{Case Report}

NE, a 56-year-old woman, who had a typical history of guinea worm extraction, attended the Enugu Specialist Hospital, Enugu, on 2nd March 1972. The left tibia was so completely necrotic that above knee amputation was carried out. An exuberant ulcer occupied most of the anterior portion of the middle threefifths. On section, several parts of the ulcer showed whitish infiltrating tissue. On microscopy, there was wide invasion by a well differentiated, highly keratinizing, squamous cell carcinoma Muscle was compressed and attacked. Fairly large blood vessels were permeated and thrombosed. Another odd feature was focal calcification of the tumor in parts. Indeed, the malignancy ranged from near innocence to bizarre pleomorphism.

\section{Discussion}

The story of the guinea worm from Nigeria is that of an infection approaching eradication [3]. From India, two cases were deemed to present merely in terms of requiring surgical removal of calcified worms [4].

Concerning the eradication, the initiative has been warming up in several parts of the world. Indeed, the Swiss group [5] concluded thus: A campaign to eradicate the disease was launched in the 1980s and has made significant progress. The strategy of the campaign is discussed, including water supply, health education, case management, and vector control. Current issues including the integration of the campaign into primary health care and the mapping of cases by using geographic information systems are also considered. Finally, some lessons for other disease control and eradication programs are outlined.

Elsewhere, as the senior author found out that by 1806 [6], the association of leg ulcer and malignant change could not be recognized. Today, chronic ulcers are becoming common in general. What is rare is the case of past leprosy being associated with chronic leg ulcer [7].

\section{References}

1. Onuigbo WIB, Ojukwu JO (2018) Guinea worm, leg ulcer, and malignant change in Nigeria: Case Report. Orthop Rheumatol 9(5): OROAJ. MS.ID.555771.

2. Perry EHO (1976) Principles of medicine in Africa. Oxford: Oxford University Press, UK, pp. 464.

3. Greenwood B, Greenwood A, Bradley A (2017) Guinea worm infection in northern Nigeria: Reflections on a disease approaching eradication. Trop Med Int Health 22(5): 558-566.

4. Gulanikar A (2012) Dracunculiasis: Two cases with rare presentations. J Cutan Aesthet Surg 5(4): 281-283.

5. Cairncross S, Muller R, Zagaria N (2002) Dracunculiasis (guinea worm disease) and the eradication initiative. Clin Microbiol Rev 15(2): 223 246.

6. Onuigbo WIB (2017) Cancer originating in leg ulcers was unknown in 1806. Int J Res Stu Med Health Sci 2(6): 1-2.

7. Onuigbo WIB, Macrae MA, Garrett AE (2018) Past leprosy and present cancer associated with chronic leg ulcers. Orthop Rheumatol 9(5): OROAJ.MS.ID.555774. 
CC (i) Commons Attribution 4.0 License BY DOI: 10.19080/OROAJ.2018.12.555842
Your next submission with Juniper Publishers will reach you the below assets

- Quality Editorial service

- Swift Peer Review

- Reprints availability

- E-prints Service

- Manuscript Podcast for convenient understanding

- Global attainment for your research

- Manuscript accessibility in different formats

( Pdf, E-pub, Full Text, Audio)

- Unceasing customer service

Track the below URL for one-step submission https://juniperpublishers.com/online-submission.php 